\title{
Migrations and the Care of the Elderly*
}

\author{
Guita Grin Debert**
}

\begin{abstract}
The present article discusses the ways in which care work are taking on specific configurations in Brazil and Italy, based on ethnographic studies with care providers and their employers in São Paulo and Bologna. Our objective is to show that the increasing visibility of this pair of undesired people - the elderly and their caregivers - is redefining forms of dependence and giving new meanings to family relationships, state obligations and domestic life.
\end{abstract}

Key-Words: Gender, Care, Migrations, Caregiver, Maids.

* Received July 23 2015, accepted October 9 2015. Translated by Thaddeus Blanchette.

*** Professor at the Departament de Anthropology, Unicamp, Campinas, SP, Brasil.ggdebert@uol.com.br 
In the presentation of a special number of The International Journal of Ageing and Later Life, Andreas Hoff, Susan Feldman and Lucie Vidovicova (2011) affirm that today's debates regarding care combine two different discourses. The first discusses the difficulties created by the increase in the world's population of elderly, while the second deals with problems created by the decline of traditional family structures. Two contrasting solutions are given for the dilemma posed by reduced suppliers of care in the face of increased demand for the same. In each, different social actors are understood to be the primary agents responsible for a possible resolution of this dilemma.

The first solution understands the provision of care to be a social responsibility and not a private issue. This point of view holds the State to be principally responsible for the care of the elderly, with social policy being paid for by taxes. Ample provision of institutional care is what's looked to here, with those families who prefer to look after their own elderly members being recompensed by the State.

Contrasting with this solution is a tendency which advocates the traditional role of the family in caring for the elderly. This second solution is ever more difficult to sustain, according to the authors, particularly when one pauses to reflect that family income is ever more dependent on the paid labor of both members of a couple. ${ }^{1}$

The aim of the present article is to discuss the way in which care of the elderly is gaining specific configurations in both Brazil and Italy, ${ }^{2}$ based on an ethnographic study of caregivers and their employers in São Paulo and Bologna. Our goal here is to show that the increased visibility of this often overlooked and even undesirable pair (old people and their caregivers) is redefining

\footnotetext{
1 Regarding the working couple and the challenges of caregiving, see Lewis (2011).

2 Regarding the reinvention of old age in the Brazilian context, see Debert (1999).
} 
forms of dependence and giving new meanings to family relations, state obligations, and domestic life itself.

\section{Brazil and the second abolition of slavery}

Any discussion of home care of the elderly in Brazil must take into account the figure of the domestic or maid and the services she provides, even in those cases where the elderly person's primary caregiver is a co-residential child, spouse or other relative. These services involve cleaning, food preparation, and other activities geared towards the maintenance of domestic life, which certainly reduce the burden of caring for the elderly (Santos \& Rifiotis 2006). ${ }^{3}$

Maids have been a constant presence in Brazilian households since the colonial period and slavery days. Brazil was the last western nation to abolish slavery and, as we shall show below, the concept of slavery marks reflections regarding domestic labor to this day, particularly in the context of the on-going debate over domestic laborer rights.

To be able to afford domestic servants was the privilege of as elite few in colonial times, principally the free owners of slaves. Today, being able to employ a maid is no longer a privilege restricted to the ruling classes. It is difficult to know how many maids there are in the Brazilian population, but Brazil is one of the biggest employers of this sort of worker in the world. ${ }^{4}$ Officially, there are some seven million domestic workers in the country. Only $30 \%$ of this total has a legal, signed work contract, however, even though this has been the law of the land since 1973 (PNAD). In other words, more than two thirds of Brazil's maids are currently working under illegal conditions. According to the International Labour Organization, Brazil has more domestic laborers than any other nation in the world, with some $15 \%$ of the economically active female population engaging in this form of labor, which is

\footnotetext{
3 Regarding care, gender and social class in Brazil see Sorj and Fontes (2012).

${ }^{4}$ International Labour Organization (2013).
} 
the third most common profession exercised by Brazilian women (IBGE). ${ }^{5}$

Studies show that even though maids can be found in the households of all classes, this in and of itself is a symptom of the reproduction of social inequalities. Elvira and Vera are both maids who we interviewed in the course of our research and their relationship demonstrates this situation quite well.

Elvira is 35 years old. She is a maid for a family that lives in a middle class neighborhood in São Paulo. Elvira lives with her children in one of the city's poorest neighborhoods. Ever since her second child was born 12 years ago, she has worked from Monday to Friday cooking, cleaning and taking care of her bosses' children. She only comes home on the weekends in order to be with her children, clean her own house and attends services in an Evangelical church in her neighborhood. She claims she works hard in order to pay a monthly wage to Vera, her neighbor, who took care of Elvira's children when they were little and who today "does everything" in Elvira's house. Even though her children are now older, Elvira still worries that they might forget to turn off the gas stove, leave the windows open, or involve themselves with the neighborhood's "dangerous crowd".

Vera was a seamstress, but she left formal salaried labor in a garment workshop in order to look after her own children when they were small. In order to be able to count on a small monthly income, she started doing what she considers "odd jobs", such as cooking for and taking care of her neighbors' children while her neighbors work as live-in maids in the city center.

Domestic labor has been passing through a series of changes recently in Brazil, however. In 2013, Constitutional Amendment $62 / 2013$ was approved, recognizing that domestic workers had the same fundamental labor rights guaranteed to any other employee, such as indemnification in the case of dismissal without cause,

${ }^{5}$ In 2011, the International Labour Organization (ILO) recognized the fundamental rights of domestic workers for the first time (Convention 189 on Decent Work as Domestic Workers). 
unemployment insurance, extra pay for night-shift work, additional remuneration for night-shift work, family bonuses, overtime pay, limited hours of work in a week, a severance pay indemnity fund system and occupational accident insurance.

These changes were amply discussed in the Congress and in the mainstream and electronic media at the time. There was a wide and impressive consensus among many different actors along all points of the political spectrum that the new law, generally known as the "maids' amendment", represented a concrete advance in the direction of a more just society. This moral consensus among political opponents was the fruit of the strict relationship the institution of "maid service" has had in Brazil with our slave-holding past.

The relationship between maids and slavery was foregrounded in an article entitled "The second abolition of slavery for Brazilian domestic workers" ("Seconde abolition de l'esclavage' pour les domestiques brésiliennes") ${ }^{6}$ published in the French newspaper Le Monde. This title reproduced the words of the president of the National Federation of Domestic Workers, Creuza Maria Oliveira, who was quite visible in the press in 2013 during the voting surrounding the constitutional amendment. According to Oliveira, domestic labor's origins could be found in slavery and the new law "not only gives us equal rights, but also social inclusion and historic reparations". ${ }^{7}$

Elvira already had a signed workers' card, establishing her, officially, as a domestic laborer. Showing us her card, she said she could now hold her head up and say with pride that she was a maid, repeating a slogan that many of the maids interviewed by the media had repeatedly said, upon hearing news of the constitutional amendment's passage. Vera, however, says that she herself is not a maid. She's just helping a neighbor and receives a monthly tip: it's not a salary, "it's just a little help". By saying this, she made it clear that she was not going to demand her rights as a

${ }^{6}$ Bourcier (2013).

7 Oliveira (2013). 
domestic worker in the courts, as the formalization of her labor contract would make it impossible for Elvira to hire her.

It was ethically impossible to criticize the new Brazilian law regarding domestic labor. The difficulties that the amendment would bring to both workers and employers, however, were emphasized in the media, along with fears of possible unemployment due to the increased costs of labor and a reduction in the demand for maids. The difficulties that maid-employing families faced also appeared in news stories, but always prefaced with affirmations that the new law was an absolute and unequivocal advance in social and political terms. Economists calculated that the new law would increase the cost of labor by 10$15 \%$, but the cases related in the media gained a tragic dimension that went far beyond cold, hard numbers.

Take, for example, the story printed by the newspaper Folha de S. Paulo ${ }^{8}$ dealing with the new legislation. This told the story of Ana, a secretary, who made $\mathrm{R} \$ 1.200,00$ a month and paid a woman $\mathrm{R} \$ 1.000,00$ a month in order to take care of her mother. Ana was forced to give up her job because her 85 year old mother, who suffered from Alzheimer's, needed full-time care. With the new law, Ana needed to pay overtime and additional time for work at night, as well as hire two additional caretakers so that she'd not exceed the 44 hour a week work limit. "I can't see another solution other than quitting my job," she said. "I am not going to institutionalize my mother. It would kill her." Ana also claimed that she wasn't able to sleep, worried as she was about living with her mother. She had already once done this for two years and almost went crazy, "because I didn't have a life of my own". Her mother had hallucinations and crises, interspersed with moments of clarity in which she repeatedly said that she "didn't want to be a bother".

Summing up, then, the Brazilian case shows that public policies can end up promoting the traditional care model, even when it is an unintended side effect, since care of the elderly is left

8 Estarque (2013). 
to the family. Studies have also shown that even though there are now more male caregivers, this work largely remains the responsibility of women.

Geriatrics and gerontology specialists consider that the elderly largely seem to prefer to be cared for by their family. They all know that family structure has passed through deep transformations. Today, both men and women, of all classes, tend to have paid employment that they spend several hours of their day performing. The difficulties that this situation presents for family care of the elderly is typically given two kinds of solutions: on the one hand, the view that the State should offer financial resources to people who take care of their elderly relatives and who thus have to leave the job market; on the other the idea that payments given to a caretaker may be discounted from a family's tax return.

\section{Slavery in Europe?}

In some European countries, and particularly in Italy (Andall and Sarti, 2004) and Spain (Escrivá, 1997; Sole e Parella, 2003), a peculiar relationship has been established between the family and the State when it comes to care of the elderly. This relationship has come to be known as "the Mediterranean welfare system" (Scrinzi, 2004). In it, families utilize low-wage foreign labor - particularly that of illegal immigrants - to take care of their elderly.

In their book Anziani e Badanti (2010), Bárbara Da Roit and Carla Facchini show that, since the end of the 1990s, a new sort of caregiver has appeared in Italy who has become more visible and who has radically transformed the care of the elderly who can't look after themselves. This is the badante: "an immigrant women employed as a domestic laborer who assists in caring for the elderly and who generally resides in their home" (Da Roit; Facchini, 2010:11). The number of badanti in Italy is not known, given the illegal status of many of these immigrants. However, many people estimate their numbers at between 700,000 and a million: many 
more caregivers than are currently employed in the formal sector of the economy.

Over the past decade, the market for badanti went through a transformation. Caregivers from Latin America, Africa and Asia were substituted by immigrants from Eastern Europe. Little attention has been given to the configurations of this market and the ways in which gender and nationality operate in terms of employers' classification of workers.

As Sofia (who at the time of her interview had just hired an immigrant from the Republic of Moldova to take care of her elderly father) explains it, Eastern European immigrants are more in demand than the Peruvians or Phillipinas (who once dominated this market) as they are presumed to have higher levels of education, more experience in caring for the elderly and, above all, are older. This last point is explained by the fact that they do not need to take care of their own children, are not on the look out for boyfriends, do not go to dances and, in short, are more available for care work. The Phillipinas and Latin Americans are preferentially hired to look after children while Africans are hired for domestic labor, cleaning and cooking because (according to Sophia) this sort of work requires more physical energy and strength.

The reasons for this migration from Eastern Europe have to do with the demise of the Soviet Union, and the unemployment and low wages in the countries that once formed it. Data on caregivers for the elderly in East Europe require a reassessment of the traditional view of migration, not only because these migrants are women, but also because they are older or middle-aged women with relatively high educational levels.

Danya is an example of the caregivers I talked to. She is 52 years old and is from the Republic of Moldavia. She had been in Bologna for 18 months when I first met her and was taking care of a 91 year old woman. As a history teacher in her homeland, she made 40 Euros a month. In Italy she made a monthly wage of a thousand Euros as a caregiver and was able to send 800 of this each month to her family. Her expenses were few in Italy because 
room and board were guaranteed in the house of the woman she cared for. On her weekly Sunday break, she liked to go window shopping with friends. Danya was separated from her husband and the money she sent to Moldavia paid for her two children's education. Both of her children were adults and one of them was expecting his first child. Danya told me that she was able to save money enough to plan a visit back home to see her children and meet her first grandchild. She had already planned for her cousin to come to Italy to substitute for her at her job during the two weeks she'd be away.

The idea of a return to one's country of origin in the near future was expressed by all the European badanti I interviewed. The Peruvian women I contacted, even those who cared for and lived with the elderly, are younger than the Europeans. When these women have children, they say they are still very young and that their mothers (the children's grandmothers) take care of those who are still in Peru. The women aim to bring these children to Italy as soon as possible. Many of the interviewees say that they are building houses back home to live in or to rent out upon retirement. They say they know that after their experiences in Italy, it will be very difficult for them to readapt to life in Peru. As one of my interviewees put it, "There [in Peru], the men are very macho and the women very antiquated". What these women wish for in terms of work is to be able to stop living in their employers' houses and to be paid per hour worked cleaning or caring for children or the elderly.

The flow of Europeans immigrants to Italy, in other words, is mostly made up of older women. If, in the case of the Latin American and Phillipina women, the grandmothers stay at home to care for the immigrants' children, in the case of the East Europeans, it's the grandmothers who immigrate in order to offer better life conditions for the children who stay at home.

The intertwining of care work with national and cultural differences also is present in the accusatory categories that characterize the disputes in the immigrant labor market. 
In the hierarchy of characteristics that make up a good caregiver, if education is used as a criterion, the women from Eastern Europe are at the top. But the Latin Americans I interviewed claim these women are cold and calculating and that they'll agree to work for any wage because, deep down, what they want is to marry the elderly person in their care in order to be able to legalize their status and improve their lives. In the same way, these women report that one never knows what Asians are thinking, as they are always smiling and no one knows why. Meanwhile, the Africans are characterized as backwards, originating in a society where nothing is clean and there is no education. One of the Peruvians interviewed claimed that "we know how to care for and respect the elderly, we learn how to do this with the old people in our own families".

It is quite impressive how conventions related to ethnicity, nationality and gender give a specific dynamic to this market. Culture is seen as a static and essentialized identity, set apart from the historical construction of social relations. Responsibility for care becomes a naturalized national vocation among immigrant women, as evidenced in all the discourses I collected regarding employment in caring for the elderly.

To deal with the badanti is to come face to face with a significant rupture in the image of the traditional family as a caring unit. Research in Italy shows that, different from what occurs in other Western European countries, the extended family network and the non-remunerated female labor are traditionally the most important sources of care for the elderly. Many authors have shown that informal care work is a key aspect of all welfare state models. ${ }^{9}$ Italian researchers, however, believe that, as is the case with Brazil, this kind of labor has assumed much greater importance in Italy, a country which has the lowest female employment rate in Europe. But the family's willingness to care for the elderly is threatened not only by the growth of female

9 There is a vast bibliography regarding welfare state models. Lewis (2001) and Knijn \& Smit's (2009) articles are particularly interesting. 
employment and the decreasing number of children in both countries, but also by increases in life expectancy, which has lead to an increase in the number of elderly people who have lost their autonomy and therefore to an increase in the number of people who are dependent upon care. These processes, which have taken place in several European countries, have introduced reforms in the care of dependent senior citizens, who come to be seen as a new social risk, requiring the creation of new services. In Italy, however, there has been a delay in the development of public policies related to old age. This is one of the reasons most often cited by researchers in order to explain the emergence and importance of the badanti. The possibility of developing in-home private care activities via this gray area of illegal labor ensures access to this type of service for large sections of the population, making Italy the country of the badanti. ${ }^{10}$

In other words, lack of social services and the availability of low-cost labor combine with little effective regulation of migratory flows and labor to support a market for care work that is dominated by migrant women. ${ }^{11}$ This transformation shows the shift from a family care model to one based on migrants working while housed within the family. The children of the elderly thus become managers of care workers in the new model, with informal domestic work being a relatively cheap solution to the need for care. The average salaries in this market, in Italy, range from 800 to 1000 euros a month for workers providing 24 hour a day care at least six days of the week. Obviously, a large part of the Italian population does not have the resources to pay for this labor, were it to be regulated.

As one Italian woman interviewed by Monica Russo put it:

Look, I'm a worker and we put aside 900 euros a month.... I spend practically all of this on her [the badante's] salary, but

\footnotetext{
${ }^{10}$ Cf. Vietti (2010).

${ }^{11}$ Ironically, this migrant labor is characterized as a form of "welfare leggero". Cf. Ambrosini \& Cominelli (2005).
} 
there is $\mathrm{n}$ o other solution... My mother can't care for herself, let's be serious here... if she lives for another two, three years, what do I do? Quit my job to look after her? And afterward, when my mother is no longer with us, at my age, how am I going to find a new job? I don't have an alternative. We live on my husband's salary and mine pays for the badante. It's hard, you know? And God forbid that my husband's mother doesn't also become ill. ${ }^{12}$

For some authors, the global flow of the young from poor countries to care for the exponentially growing elderly population of the rich countries reveals one of the rawest forms of human destitution. Arlie Russell Hochschild's in Love and Gold (2002) succinctly expresses the changes that have taken place in the relationship between the developed world and the poorer nations of the globe. If in earlier centuries, colonialism concentrated on exploiting goods and resources, today love and care for children and the elderly are the "goods" which are configuring the international flow of people.

Other authors, however, try to show that the situation is much more ambiguous. In opposition to more structural forms of analysis, these writers seek to emphasize the ways in which caregivers' lives are lived in different contexts and how negotiation is possible even in the most fragile of the relationships created in this context. According to this perspective, the private market provides an apparently winning strategy for all the actors involved: the elderly, their families, the immigrant worker and those who are responsible for public policies regarding care work. For the elderly and their families, it is an affordable and affectively potent

\footnotetext{
12 "Guardi che io faccio l'operaia, guadagno si e no 900 euro al mese... praticamente li verso quasi tutti per pagare lo stipendio a lei ("la badante"), ma non so come fare diversamente.. mia madre adesso non è autonoma, ma parliamo seriamente... se vive altri due, tre anni, quelli che sono, è tanto... allora io cosa faccio? Mi licenzio per starle dietro? E poi, quando mia madre non ci sarà più, alla mia età, cosa crede che trovo un altro lavoro? io non ho alternative, viviamo con lo stipendio di mio marito, e col mio paghiamo la badante. È difficile sa? E Dio non voglia che si ammali anche la madre di mio marito..."
} 
alternative to nursing homes or other long-term institutionalized care options for the elderly (which are generally seen as "death's waiting room"). For the immigrant worker, it means being able to earn a monthly salary that is much larger than that available in their countries of origin. Aside from this, living in the home with the elderly not only means savings in terms of room and board, but it is also a means of protecting oneself from the illegality of one's migratory situation.

The caregivers that I interviewed in Bologna were all very satisfied with the relationship that they had established with the elderly in their care and the families they lived with. But all of them also had stories to tell of family members who arrived late on Sundays and in such a regular fashion that the caregivers were never sure when their weekly day off would or could begin (given that the elderly in their care cannot be left alone). They also told stories of women who'd bring all their laundry to their elderly father's house so that the badante could clean and press it. And there were many cases of late payments or discounts in the caregiver's salary.

Parreñas (2001) has shown that caregivers (even those with legal residency and work documents) have only partial citizenship, at best. The international literature on gender and migration has also strongly denounced the abuses that are often involved in this sort of work situation: sexual and physical violence, endless hours of work, humiliating treatment and restrictions on moving about the employer's house. However, as Mônica Russo has pointed out (2008), it must be recognized that negotiation is a part of all of this work and that these negotiations are quite different from those involved in labor contracts. Emotional and psychological factors are always part of the back-and-forth and these demand a dynamic, contextualized and frequently conflict-ridden interaction, given that the duties and responsibilities of the different actors in the household are redefined on a day-by-day basis, reinforcing or blurring the borders between the domestic and labor spheres of interaction. 
Finally, this privatized care market is also, ironically enough, a winning strategy with regards to public policy, given that politicians presumably see a considerable reduction in demands for better social services or revisions of public policy with regards to an increasingly graying population.

This transformation thus consists of a shift from family care to care by an immigrant embedded in the family, in which the children of the elderly (and their daughters, in particular) take on the role of care-worker mangers.

It is thus with some degree of reason that Brett Neilson (2003), in pointing out the importance of being aware of how processes of globalization and aging are mutually entwined, employs homo sacer in his analysis, in the sense proposed by Giorgio Agamben (1995). This personage, taken from ancient Roman law, designates someone who judged and condemned for a crime and who cannot be sacrificed but who can, nevertheless, be killed without their killed being judged a murder. Neilson believes that homer sacer adequately portrays the situation of the illegal immigrant worker, stripped of citizenship rights and living in the most complete insecurity, largely seen by her surrounding society as a criminal or even a potential terrorist.

The flow of young workers from poor countries to rich countries, in order to care for elderly of those latter nations, is caused by an increasing division of wealth and employment in a globalized world, as Neilson shows. This pushes an increasing number of people to risk traversing the barriers raised against illegal immigration by rich countries. This migration, overseen by the detention and deportation system, can often set up forms of labor practices that bear a striking resemblance to and often even continuity with practices of slavery. Far from being archaic, these working arrangements are in fact constitutive of a form of capitalist development that seeks to limit the mobility of workers through a continuous process of replacing people who are willing to accept low-paid work and low status, such as taking care of the elderly. Immigrant workers live in a state of complete uncertainty because they are labeled as illegal, criminal or even as potential terrorists. 
These labels are perpetuated not only by nationalist or nativist political forces and the political right, but also by conservative leftist organizations that associate the defense of the remaining disciplinary mechanisms of the nation state (particularly the welfare and centralized pension systems) with an anti-immigrant agenda.

\section{Slavery and respectable families: moving towards a provisional conclusion}

The landscape of the great urban centers of both Brazil and Italy, particularly in these cities most affluent neighborhoods, is full of older men and women who are accompanied by younger women who are responsible for providing care for the elderly. In Brazil and other countries characterized by bitter economic and social inequalities, maids (usually young women from small towns or rural areas) have throughout history carried out household chores and cared for children and the elderly. In Italy, it can be said that professional caregivers (in this case immigrant women from poorer countries) are relatively new upon the scene. Their presence imposes a new design upon public space in which that undesirable dual, the dependent elderly and their immigrant caregivers, is increasingly visible. Similarly, private spaces, especially the households that rely on caregivers, become a kind of exotic microcosm transplanted to Europe. ${ }^{13}$

The labor market for live-in caregivers is expanding, developing in response to increased life expectancies and giving new meaning to the flow of migrants from poorer to richer countries. This new reality imposes new configurations upon the personal relationships within families, upon employment contracts and upon people's perceptions regarding the duties and obligations of the State.

\footnotetext{
13 "Exotic microcosms transplanted to Europe" is an expression created by Scrinzi (2004).
} 
As we have shown above, those who attempt to address the issue in Brazil tend to praise the new legislation, which extends labor rights in the formal market to domestic workers and promoting what has been perceived as a second abolition of slavery. By contrast, in the northern countries, the illegal immigrant caregiver is perceived as an introduction of slavery into the heart of the world's richest democracies.

Talk about slavery, however, dismisses caregivers' capacity for agency, in much the same way as occurs in discussions regarding the transnational market for prostitution. As Scrinzi shows (2004), by describing prostitutes from poor countries as passive victims of traffickers from their homelands, one extols the centrality of the European model of empowerment for women, creating a boundary between the "European woman" and those to whom this condition is denied. It obscures the fact that for many women, prostitution circuits are the only means available for migration to the European Union. Far from denying the reality of these women's dramatic stories, Scrinzi suggests that by seeing the prostitution system only in strictly moralist terms, seeing in it only the violent practices, is to forget that these women are the "abjectified" margins that contain and surround the idea of "respectable" femininity.

Similarly, it can be said that by restricting attention regarding the phenomenon of domestic migrant workers to sensational cases of "modern slavery", one forgets that the live-in caregiver is an active element in the production of the "respectable family"; a family that keeps their elderly their own roof by recruiting, paying and managing the work of caregivers who are poor and stripped of citizenship rights. These caregivers, legal or illegal, are the "abject margins" because they have abandoned their families, their young children and their elderly relatives in search of better living conditions in other countries.

The boundaries between trafficking, prostitution and the labor of migrant workers are often blurred or gain unusual meanings. One project in the Northern Rhine-Westphalia region of Germany aims to train prostitutes as caregivers for the elderly. This 
initiative was presented as "very logical", ${ }^{14}$ given that there is a shortage of caregivers in nursing homes. Despite the high level of unemployment in the country, a crackdown on illegal immigrants who were in engaged in this sort of care and a lack of interest on the part of Germans to do this sort of work has resulted in a continued demand for caregivers. Additionally (according to the program's promoter), prostitutes make excellent caregivers because they have "good people skills, aren't easily disgusted, and have zero fear of physical contact".

What is evident in both Italy and Brazil is a horror of institutionalization. There are obviously reasons for this: nursing homes are perceived as death's waiting rooms and warehouses for useless people. This horror has a generational aspect, too, given that today's middle-aged adults grew up during the 1960s a period of a significant deinstitutionalization movement and this, in turn, is making it difficult to imagine innovative and creative forms of housing for the dependent elderly. It also prevents the recognition that dependence is not synonymous with lack of interest in active social life and in going beyond family boundaries and even making living with one's family more rewarding.

In Brazil, we have a new law that promises to change the situation of domestic workers. Will demand for domestic labor suffer? Will lawlessness and an absence of contracts be maintained at current levels or will it increase? In Italy, immigration has created new configurations in the relationship between the family and care for the elderly. Are these transient changes, given the limits on immigration and the struggle for existing legislation prohibiting illegal to be enforced more effectively? Will there be an expansion of training programs which seek to transform older prostitutes into caregivers for the elderly? As a result will caregivers have a new profile and/or be subject to new prejudices? It is hard to know anything for sure at this point. What we believe is that our research, the texts we produce and the answers we offer identify dramas that will play a central role in the destiny of caregivers for

${ }^{14}$ Regarding this theme, see Duke (2006). 
the elderly and in the ways in which dependence is understood and lived.

\section{Bibliography}

Agamben, Giorgio. Homo Sacer: o poder soberano e a vida nua. Belo Horizonte, Editora UFMG, 2002.

Ambrosini, Maurizio; Cominelli, Claudia. Un'assistenza senza confini. Welfare 'leggero', famiglie in affanno, aiutanti domiciliari immigrate. Milano, Ismu-Regione Lombardia, 2005.

Andall, Jacqueline; Sarti, Rafaella. Le trasformazioni del servizio domestico in Italia: un'introduzione. Polis Ricerche e studi su società $e$ política in Italia, 18(1), Bologna, Società Editrice Il Molino 2004, pp.5-16.

Bourcier, Nicolas. "Seconde abolition de l'esclavage" pour les domestiques brésiliennes. Le Monde (Amériques), 29 mar. 2013 [<http://www.lemonde.fr/ameriques/article/2013/03/29/secondeabolition-de-l-esclavage-pour-les-domestiquesbresiliennes_3150200_3222.html\#ElHUcftu4jTFc8pV.99> - acesso em: 17 mai. 2015].

Brett, Neilson. Globalization and the Biopolitics of Aging. the New Centennial Review, vol. 3, n², Michigan, Michigan State University Press, summer 2003.

Da Roit, Barbara; Facchini, Carla. Anziani e Badanti - Le differenti condizioni de chi è accudito e di chi accudisce. Milano, Franco Angeli, 2010.

Debert, Guita Grin. A Reinvenção da Velhice: Socialização e Processos de Reprivatização do Envelhecimento. São Paulo, EDUSP, 1999.

Duke, Katy. Project retrains prostitutes as care workers for elderly people. British Medical Journal (BMJ), 332 (7543), 685, 2006 [<http://www.ncbi.nlm.nih.gov/pmc/articles/PMC1410850/> - acesso em: 17 mai. 2015].

Escrivá, Angeles. Control, Composition and Character of New Migrations to South-West Europe: the case of Peruvian Women in Barcelona. 
Journal of Ethnic and Migration Studies, 23(1), New York, Routledge, 1997, pp.43-57.

Estarque, Marina. Alta de custo com cuidadores muda rotina da família. Folha de São Paulo - Caderno B, pp.6, 20 abr. 2013.

Guimarães, Nadya Araújo; Hirata, Helena; Sugita, Kurumi. Cuidado e Cuidadoras: o trabalho de care no Brasil, França e Japão. In: Guimarães, Nadya Araújo; Hirata, Helena (orgs.). Cuidado e Cuidadoras - as várias faces do trabalho de care. São Paulo, Editora Atlas, 2012, pp.79-102.

Hochschild, Arlie Russel. Love and Gold. In: B. Ehrenreich, Barbara; Hochschild, Arlie Russel (orgs.). Global Women - nannies, maids, and sex workers in the new economy. New York, Henry Holt and Company, 2002, pp.15-30.

Hoff, Andreas; Feldman, Susan; Vidovicova, Lucie. Migrant home care workers caring for older people: fictive kin, substitute, and complementary family caregivers in an ethnically diverse environment. International Journal of Aging and Later Life, vol. 5(2), Linköping, Linköping University Electronic Press, 2011, pp.7-16.

IBGE - Instituto Brasileiro de Geografia e Estatística. Pesquisa Nacional por Amostra de Domicílios (PNAD) - Comentários on-line. 2011a [<ftp://ftp.ibge.gov.br/Trabalho_e_Rendimento/Pesquisa_Nacional_p or_Amostra_de_Domicilios_anual/2011/Sintese_Indicadores/comentar ios2011.pdf $>$ - acesso em: 17 mai. 2015].

IBGE - Instituto Brasileiro de Geografia e Estatística . Pesquisa Mensal de Emprego: Algumas das principais características dos Trabalhadores Domésticos vis a vis a População Ocupada. 2011b [<www.ibge.gov.br/.../princ_carac_trab_dom.pdf> - acesso em: 17 mai. 2015].

International Labour Office. Domestic workers across the world: Global and regional statistics and the extent of legal protection. Geneva, ILO, 2013

[<http://www.ilo.org/global/publications/books/WCMS_173363/lang-en/index.htm $>$ - acesso em: 17 mai. 2015].

Knijn, Trudie; Smit, Arnoud. Investing, Facilitating, or Individualizing the Reconciliation of Work and Family Life: Three Paradigms and Ambivalent Policies. Social Politics, 16(4), 2009, pp.484-518. 
Lewis, Jane. The Decline of the Male Breadwinner Model: Implications for Work and Care. Social Politics, 8(2), 2001, pp.152-169.

Oliveira, Creuza Maria. Creuza Maria Oliveira: Uma reparação histórica. Folha de São Paulo, Opinião, 28 mar. 2013. [<http://www1.folha.uol.com.br/opiniao/2013/03/1253293-creuzamaria-oliveira-uma-reparacao-historica.shtml > - acesso em: 17 mai. 2015].

Parreñas, Rhacel. Transgressing the national state: partial citizenship and "imagined (global) community" of migrant Filipina domestic workers. Signs: Journal of Women in Culture and Society, 26 (4), 2001, pp.1129-1154

[<http://www.jstor.org/stable/3175359?seq=1\#page_scan_tab_conte nts > - acesso em: 17 mai. 2015].

Russo, Monica. Donne Migranti a Modena: il Lavoro di "badante" tra Vincolo e Risorsa. Tese (Doutorado). Cooperazione Internazionale e Politiche per lo Sviluppo Sostenibile. Ciclo XIX. Bolonha, Alma Mater Studiorum, Università di Bolonha, 2008.

Santos, Sílvia Maria Azevedo; Rifiotis, Theophilos. Cuidadores familiares de idosos demenciados: uma reflexão sobre a dinâmica do cuidado e da conflitualidade intrafamiliar. Laboratório de Estudo das Violências/UFSC, Florianópolis, 2006 [ $<$ https://www.academia.edu/3059020/Cuidadores_familiares_de_ido sos_dementados_uma_reflex\%C3\%A3o_sobre_a_din\%C3\%A $\overline{2}$ mica do_cuidado_e_da_conflitualidade_intra-familiar $>$ - acesso em: $\overline{17}$ mai. 2015].

Scrinzi, Francesca. Professioniste della Tradizione. Le donne migranti nel mercato del lavoro domestico. Polis: Ricerche e studi su società $e$ política in Italia, 18(1), Bologna, Società Editrice Il Molino, 2004, pp.107-136.

Solé, Carlota; Parella, Snia. Migrant Women in Spain: Class, Gender and Ethnicity. In: Andall, Jacqueline (org.). Gender and Ethnicity in Contemporary Europe. Oxford, New York, Oxford University Press, 2003, pp.61-76.

Sorj, Bila; Fontes, Adriana. O care como um regime estratificado: implicações de gênero e classe social. In: Guimarães, Nadya Araújo; 
Hirata, Helena (orgs.). Cuidado e Cuidadoras - as várias faces do trabalho de care. São Paulo, Editora Atlas, 2012, pp.103-116.

Vietti, Francesco. Il Paese delle Badanti. Roma: Meltemi Editore, 2010. 